\title{
HABITAT UTILIZATION AND WINTER TIME-ACTIVITY BUDGETS OF THE WHOOPER SWAN CYGNUS CYGNUS (LINNAEUS, 1758) POPULATION WINTERING AT THE VAN LAKE BASIN, TURKEY
}

\author{
NERGIZ, $\mathrm{H}$. \\ Bitlis Eren University, Faculty of Arts and Sciences, Department of Biology, Bitlis, Turkey \\ (e-mail: humeyranergiz@gmail.com) \\ (Received 23 $3^{\text {rd }}$ Nov 2018; accepted $16^{\text {th }}$ Jan 2019)
}

\begin{abstract}
In this study, daily behaviour patterns of whooper swans (Cygnus cygnus) were studied at the Van Lake Basin, which is one of the most important wintering areas of the species in Turkey. Wintertime activities of the swans were monitored from sunrise to sunset in 6 different categories: resting, feeding, preening, walking on land, swimming and flying. The most common daytime activity was resting $(55 \%)$. Feeding $(12.48 \%)$ and preening $(10.98 \%)$ were the two other main diurnal activities of whooper swans during the present study. Resting peaked in midday period (08:30-13:30) while feeding was observed frequently in early morning hours (06:00-8:30) and late afternoon (13:30-17:00). At the beginning of severe winter period (December and January) whooper swans clearly reduced feeding time in all parts of the day, probably because they still met metabolic demands. A significant increase in feeding behaviour was observed in January and February when they were preparing to migrate. While open water surface was the most preferred area for resting, shallow coastal areas and reeds were the most utilized foraging habitats.
\end{abstract}

Keywords: waterfowl, behaviour, diurnal period, movements, waterbirds, wetlands

\section{Introduction}

Behaviour patterns of waterbirds vary with weather conditions, food availability, threat factors and the physiological status of the species (Weathers and Sullivan, 1993; Meissner and Markowska, 2009). These behaviours that birds show under different environmental conditions offer important tips in understanding their ecological requirements. Furthermore, changes in waterbird activity may provide an earlier indication of an impact than numbers of birds (Weathers and Sullivan, 1993; Hamilton et al., 2002).

Time-activity budget studies of wintering waterbirds give information about seasonal microhabitat selection and the influence of hunting pressure, habitat alteration and other threats on behaviour (Poulton et al., 2002; Michot et al., 2006; Crook et al., 2009). In this manner, such studies can be used to evaluate habitat quality and quantity, to compare activity patterns of populations in different geographic regions and contribute to wetland management or species conservation plans (Woodin and Michot, 2006).

Whooper swan (Cygnus cygnus) is mainly a winter visitor species to Europe and Turkey. Except reproduction period, they migrate in small flocks and congregating into flocks of up to 300-400 individuals in the winter (Johnsgard, 1978; Madge and Burn, 1988). The overall population trend is uncertain. Population size in Europe is estimated at between 25300-32800 pairs and the status is shown as "LC" in the IUCN category (Anonymous, 2015a). A limited number of studies about the Turkey population of the whooper swan indicate that the species has been wintering in the Van Lake Basin since the early 1990s. The species arrives to the basin from the beginning of the winter and stays at the basin until the beginning of spring and then leaves. Depending on the year, 
the population size of the species wintering at Van Lake Basin ranges between 50-240 individuals (Adızel, 1995; Adızel et al., 2010; Azizoğlu et al., 2016, 2017; Çelik et al., 2016). In recent years, the number of individuals wintering in the Basin has increased while there is a lack of data about behaviour pattern of the species. The aim of this study was to determine the daily behaviour of a colony of whooper swan wintering in the Van Lake Basin.

\section{Materials and methods}

\section{Study area}

This research was carried out at Göründü Delta $\left(38.328637^{\circ} \mathrm{N}, 42.927174^{\circ} \mathrm{E}\right)$ in the southern part of Van Lake. Göründü Delta that located on the $58^{\text {th }} \mathrm{km}$ of Van-Bitlis highway, is a wetland with 124 ha (Fig. 1). The delta, $1648 \mathrm{~m}$ in altitude and $5 \mathrm{~km}^{2}$ in width, is an internationally important wetland that hosts large numbers of migratory and the resident waterbirds (Anonymous, 2015b; Aşur, 2017). In recent years, one of the unique habitats where the whooper swans were wintering in the eastern of Turkey is the Göründü Delta.

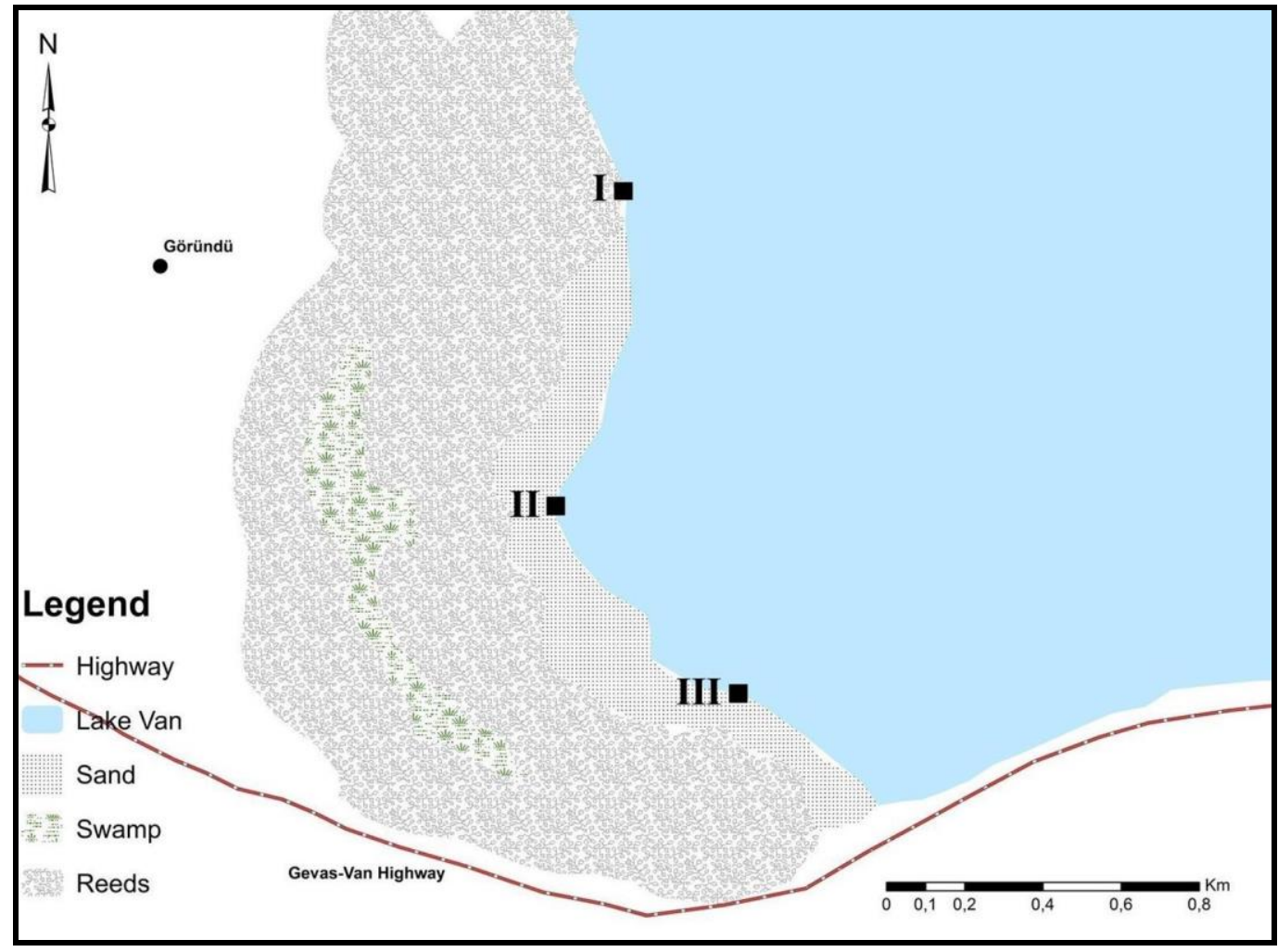

Figure 1. Observation points at Göründü Delta

\section{Behavioural observations}

In order to identify the wintering behaviour of whooper swan, observations were conducted between November 2015 and March 2016 on days without precipitation or strong wind. During this study period, a total of 70 days between November and March were used for diurnal observations. 
Scan sampling and focal sampling methods were used to evaluate different daily wintering behaviour of adults and juveniles (Altmann, 1974). The observations started in the morning before sunrise (06:00) and continued until sunset (17:00). This period was divided into 3 equal parts as morning (06:00-08:30), midday (08:30-13:30) and late day (13:30-17:00) with equal numbers of focal sample observations within them. Scan samplings were made at the beginning of each period to assess the total number of birds. When using this method, the behaviour of all individuals in a flock were recorded at predetermined time intervals during the daytime hours. In total 1540 observation sessions and $192.2 \mathrm{~h}$ of scanning were performed. Six main activities of whooper swan were evaluated in this study: resting, feeding, preening, swimming, flying and moving on land. In the determination of the behaviours, random focus observation method was used. The instantaneous behaviour of each individual in a flock with 90 individuals was recorded with a telescope in half-hour intervals. After scanning maximum 30 individuals, other individuals were evaluated as second and third groups. The scanning started from the first individual and continued towards left until the last individual. We quantified time-activity budgets by calculating the proportion of time spent in each behaviour for each focal sample.

\section{Statistical analysis}

The statistical software SPSS 20 was used to perform all statistical analyses. We identified diurnal period and winter period differences with ANOVA.

\section{Results and discussion}

During the five months of survey, daily activities of a whooper swan showed a major variation which occurred majorly due to the hydrobiological condition and ecological status of the coastal area. We detected that in winter season the whooper swans spent most of the time by resting (55\%) and the rest by feeding $(12.48 \%)$, preening $(10.98 \%)$, walking on land (8.94\%), swimming (7.73\%) and flying (4.87\%) (Fig. 2).

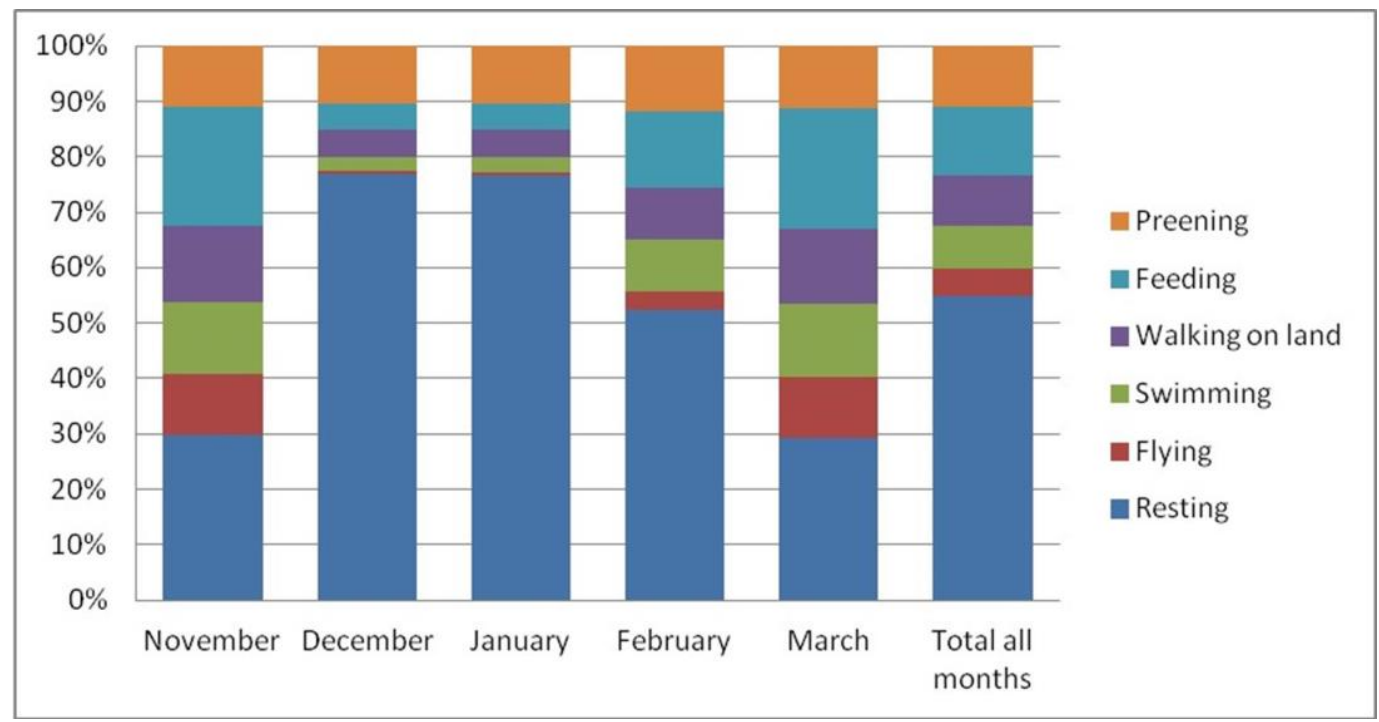

Figure 2. The percentage of time spent to the activities by whooper swan at different parts of winter time (monthly and in total) 
Resting, feeding and preening were the main diurnal activities. Resting peaked in midday while feeding was observed frequently in morning and late afternoon (Table 1). The feeding pattern recorded was similar to patterns recorded earlier studies of swans (Tatu et al., 2007; Peihao et al., 2011).

Table 1. Mean percentage of winter-time diurnal activities of the whooper swan in different time periods of the day

\begin{tabular}{c|c|c|c|c}
\hline Behaviour & $\begin{array}{c}\text { Morning } \\
(\mathbf{0 6 : 0 0 - 8 : 3 0 )} \\
\mathbf{n : ~ 4 3 . 4 5 h}\end{array}$ & $\begin{array}{c}\text { Midday } \\
\mathbf{( 0 8 : 3 0 - 1 3 : 3 0 )} \\
\mathbf{n : ~ 8 7 . 5 h}\end{array}$ & $\begin{array}{c}\text { Late day } \\
\mathbf{( 1 3 : 3 0 - 1 7 : 0 0 )} \\
\mathbf{n : ~ 6 1 . 2 5 h}\end{array}$ & Overall \\
\hline Resting & 41.8 & 62.9 & 60.3 & 55 \\
Feeding & 27.1 & 7.8 & 2.54 & 12.48 \\
Preening & 11.39 & 10.6 & 10.95 & 10.98 \\
Walking on land & 8.82 & 6.2 & 11.8 & 8.94 \\
Swimming & 7.25 & 6.74 & 9.2 & 7.73 \\
Flying & 3.64 & 5.76 & 5.21 & 4.87 \\
\hline
\end{tabular}

n: observed hour

Temperature at a wintering site is an important determinant of the waterbirds' time budgets (Guillemain et al., 2002). The temperature averages according to the months were; November $\left(4.4{ }^{\circ} \mathrm{C} \pm 0.2\right)$, December $\left(-2{ }^{\circ} \mathrm{C} \pm 0.3\right)$, January $\left(-3{ }^{\circ} \mathrm{C} \pm 0.3\right)$, February $\left(-4{ }^{\circ} \mathrm{C} \pm 0.2\right)$ and March $\left(-1{ }^{\circ} \mathrm{C} \pm 0.4\right)$. The higher average temperature in November and March compared to the temperature average of December, January and February, affected the activities of the species. Resting activity in December, January and February was significantly higher whereas more time was spent on feeding activity in November and March $(\mathrm{P}<0.05)$ (Fig. 2).

In this study, we detected that mean percentage of time spent to feeding activity was similar in November and March and the resting was similar in December and January. It was identified that all the activities in February shows temporal differences with the activities in the other months (Table 2).

Table 2. Statistical analysis of the monthly activity budgets of whooper swan

\begin{tabular}{c|c|c|c|c|c|c}
\hline \multicolumn{2}{c}{ ANOVA } & \multicolumn{6}{c}{ Subset for alpha = 0.05 } \\
\hline Behaviour & $\mathbf{n}$ & November & December & January & February & March \\
\hline Resting & 90 & $0.890667^{\mathrm{c}}$ & $2.145259^{\mathrm{a}}$ & $2.128333^{\mathrm{a}}$ & $1.448571^{\mathrm{b}}$ & $0.873056^{\mathrm{c}}$ \\
Feeding & 90 & $1.178^{\mathrm{c}}$ & $0.246^{\mathrm{a}}$ & $0.26^{\mathrm{a}}$ & $0.7608^{\mathrm{b}}$ & $1.1853^{\mathrm{c}}$ \\
Preening & 90 & $0.6107^{\mathrm{a}, \mathrm{b}}$ & $0.5789^{\mathrm{b}}$ & $0.575^{\mathrm{b}}$ & $0.6405^{\mathrm{a}}$ & $0.6226^{\mathrm{a}, \mathrm{b}}$ \\
Moving on land & 90 & $0.7457^{\mathrm{a}}$ & $0.2723^{\mathrm{c}}$ & $0.269^{\mathrm{c}}$ & $0.5233^{\mathrm{b}}$ & $0.7478^{\mathrm{a}}$ \\
Swimming & 90 & $0.7187^{\mathrm{a}}$ & $0.1409^{\mathrm{c}}$ & $0.149^{\mathrm{c}}$ & $0.5154^{\mathrm{b}}$ & $0.7238^{\mathrm{a}}$ \\
Flying & 90 & $0.6077^{\mathrm{a}}$ & $0.0375^{\mathrm{c}}$ & $0.0303^{\mathrm{c}}$ & $0.1796^{\mathrm{b}}$ & $0.6124^{\mathrm{a}}$ \\
\hline
\end{tabular}

$* \mathrm{P}<0.05, \mathrm{n}$ : individual number

When the activities of the species in November and March were considered, we revealed that diurnal activities as flying, swimming and moving on land were similar within themselves $\left({ }^{\mathrm{a}}\right)(\mathrm{P}<0.05)$, feeding and resting were homogeneous within 
themselves $\left({ }^{c}\right)(\mathrm{P}<0.05)$. Preening was totally different from feeding and resting. However it was similar with the other activities $\left({ }^{\mathrm{a}, \mathrm{b}}\right)(\mathrm{P}<0.05)$. When daily activities in December and January were considered, feeding and resting were similar with themselves $\left({ }^{\mathrm{a}}\right)$, while flying, swimming and on land movement were showing similarities within themselves $\left({ }^{\mathrm{C}}\right)$. The preening activity was independent from both groups $\left(^{b}\right)(P<0.05)$. In February all diurnal activities were similar with each other except preening (Table 2).

Results of our work confirm the findings by Squires and Anderson (1997) that swans spent more time resting as winter temperatures decreased. Percent of time spent on different daily activities differed significantly between day periods in mild and severe winter (Fig. 2). They spent the most of severe winter period inactive, apparently relaying on accumulated energetic reserves. Increasing energetic expenditure in the period of low temperatures is often compensated through more intensive and longer foraging (Guillemain et al., 2002; Meissner and Ciopcinska, 2007). However, during the harshest winter weather observation period in the Göründü Delta whooper swans reduced all daily activities primarily foraging and feeding. They spend less time on locomotion, but the most striking difference concerned feeding time. In December, January and February where the air temperature is the lowest -17 (average -4 ), the resting ratio is about 76\%, and this ratio decreases $29 \%$ in November and March.

Despite lower air temperature in late winter period (in February), whooper swans had increased the total feeding time and they were more active. Because they had to store energy and increase fat reserves before the long migration period. At the same time they begin getting the nutrient reserves required for reproduction.

Black et al. (2010) indicated that $44.9 \%$ of the daily activities of the Tundra swan (Cygnus columbianus) in the Eel River Delta were related to the foraging activities. Rees and Bowler (1991) reported a similar proportion of $48.4 \%$ feeding in swan flocks in England in late winter/spring period. According to our results, daily foraging activities of whooper swans were decreased in the late winter period but lower than these rates. We think that the most important reason for this situation is low nutrient density, food availability and different climatic conditions in Göründü Delta.

Laubek et al. (1999) pointed out that the whooper swans use open water surface while performing their daily activities during the winter months. Similarly, we observed that the whooper swans were performed almost all their daily activity in water.

\section{Conclusion}

In the Göründü Delta where ducks winter in high density, whooper swans spent most of the brief severe winter period almost inactive, probably relying on accumulated energetic reserves. Diet of whooper swans mostly consist of aquatic plants such as Algae sp., Chara sp. and Zostera sp (Brazil, 1981; Del Hoyo, 1992; Kantrud, 1990; Squires and Anderson, 1995). Since the study area is associated with Van Lake and has soda-water, it is poor in terms of water plants. This factor reduces the feeding time of the species. The whooper swans were feeding in shallow water line and reeds. The caloric value in aquatic plants is lower than in terrestrial plants (Dourado et al., 2004). During the winter the species is known also to feed on agricultural land and takes agricultural grain (Brazil, 2003). Nevertheless, grazing on land was observed just a few times only in March. Intensive hunting pressure in the field is the most important reason for this situation. More comprehensive studies about whooper swans' winter food 
supply and nutritional diversity would help to inform habitat management and protection for the swans.

\section{REFERENCES}

[1] Adızel, Ö. (1995): Researches on Ornithofauna of Van Lake Basin. - PhD Thesis, Yüzüncü Y1l University, Van.

[2] Adızel, Ö, Durmuş, A., Kiziroğlu, İ. (2010): Preliminary study on newly detected Yayliyaka Marshes in the Lake Van Basin, Turkey. - The Journal of Animal and Plant sciences 20(4): 286-292.

[3] Altmann, J. (1974): Observational study of behaviour: sampling methods. - Behaviour 49: 227-267.

[4] Anonymous (2015a): Bird Life International European Red List of Birds. - Office for Official Publications of the European Communities, Luxembourg.

[5] Anonymous (2015b): Key Biodiversity Areas of Turkey, 2: 368-387, Ankara.

[6] Aşur, F. (2017): Visual landscape quality and recreational potential of wetlands around Van Province. - Turkish Journal of Agricultural and Natural Sciences 4(4): 506-515.

[7] Azizoğlu, E., Adızel, Ö. (2017): A study on the distribution and population status of the Whooper Swan (Cygnus cygnus l. 1758) in the Van lake basin. - Natural Science and Discovery 3(2): 25-32.

[8] Azizoğlu, E., Çelik, E., Durmuş, A., Adızel, Ö. (2016): Identification of the daily displacement activities of whooper swan (Cygnus cygnus) with geographical information systems (GIS) in Lake Van. - 5th International Eurasian Ornithology Congress, May 1013, Çanakkale.

[9] Black, J. M., Gress, C., Byers, J. W., Jennings, E., Ely, C. (2010): Behaviour of wintering Tundra Swans Cygnus columbianus columbianus at the Eel River delta and Humboldt Bay, California, USA. - Wildfowl 60: 38-51.

[10] Brazil, M. A. (1981): The behavioural ecology of the whooper swan (Cygnus cygnus). $\mathrm{PhD}$ thesis, Department of Psychology, University of Stirling, England.

[11] Brazil, M. A. (2003): The Whooper Swan. - T \& AD Poyser, London.

[12] Crook, S. L., Conway, W. C., Mason, C. D., Kraai, K. J. (2009): Winter time-activity budgets of diving ducks on eastern Texas reservoirs. - Waterbirds 32(4): 548-558.

[13] Çelik, E., Azizoğlu, E., Adızel, Ö., Durmuş, A. (2016) Detection of the midwinter water bird distribution in Erçek Lake, Dönemeç and Bendimahi Deltas with geographical information systems. - 5th International Eurasian Ornithology Congress, May 10-13, Çanakkale.

[14] Del Hoyo, J., Elliot, A., Sargatal, J. (1992): Handbook of the Birds of the World, Vol. 1: Ostrich to Ducks. - Lynx Edicions, Barcelona, pp. 640-696.

[15] Dourado, E. C. S., Peretti, D., Benedito-Cecilio, E. (2004): Variability in the caloric content of vasculat plants in two Parana State reservois. - Acta Scientiarum 26: 137-142.

[16] Guillemain, M., Herve, F., Duncan, P. (2002): Foraging strategies of granivorous dabbling ducks wintering in protected areas of the French Atlantic coast. - Biodiversity and Conservation 11: 1721-1732.

[17] Hamilton, A. J., Taylor, I. R., Hepworth, G. (2002): Activity budgets of waterfowl (Anatidae) on a waste-stabilization pond. - Emu 102: 171-179.

[18] Johnsgard, P. A. (1978): Ducks, Geese and Swans of the World. - University of Nebraska Press, Lincoln and London, pp. 32-53.

[19] Kantrud, H. A. (1990): Sago Pondweed (Potamogeton pectinatus L.): A Literature Review. - Res. Rep. No. 176. U. S. Fish Wildt. Serv., Milbridge, ME.

[20] Laubek, B., Knudsen, H. L., Ohtonen, A. (1988): Migration and Winter Range of Whooper Swans Cygnus Cygnus Breeding in Different Regions of Finland (Chapter 5). In: Laubek, B. (ed.) The Northwest European Whooper Swan (Cygnus cygnus) 
Population: Ecology and Management Aspects of Expanding Waterfowl Population. PhD Thesis, University of Aarhus, Denmark, pp. 1-33.

[21] Madge, S., Burn, H. (1988): Wildfowl. - Christopher Helm, London, pp. 254-262.

[22] Meissner, W., Ciopcinska, K. (2007): Behaviour of mute swans Cygnus olor wintering at a municipal beach in Gdynia, Poland. - Ornis Svecica 17: 148-153.

[23] Meissner, W., Markowska, K. (2009): Influence of low temperatures behaviour of mallards (Anas platyrhynchos L.). - Polish Journal of Ecology 57(4): 799-803.

[24] Michot, T. C., Woodin, M. C., Adair, S. E., Moser, E. B. (2006): Diurnal time-activity budgets of Redheads (Aythya americana) wintering in seagrass beds and coastal ponds in Louisiana and Texas. - Hydrobiologia 567: 113-128.

[25] Peihao, C., Rees, E. C., Meng, S. M., Meijuan, Z., Lei, C., Barter, M., Fox, A. D. (2011): A comparison of behaviour and habitat use by Bewick's Swans Cygnus columbianus bewickii at wintering sites in China and Europe: preliminary observations. - Wildfowl 61: 52-73.

[26] Poulton, V. K., Lovvorn, J. R., Takekawa, J. Y. (2002): Clam density and scaup feeding behavior in San Pablo Bay, California. - Condor 104: 518-527.

[27] Rees, E. C., Bowler, J. M. (1991): Feeding activities of Bewick's Swans Cygnus columbianus bewickii at a migratory site in the Estonian SSR. - Wildfowl 1: 249-255.

[28] Squires, J. R., Anderson, S. H. (1995): Trumpeter swan (Cygnus buccinator) food habits in the Greater Yellowstone Ecosystem. - The American Midland Naturalist 133: 274282.

[29] Squires, J. R., Anderson, S. H. (1997): Trumpeter swan (Cygnus buccinator) activities from winter to spring in the Greater Yellowstone Area. - The American Midland Naturalist 138: 208-214.

[30] Tatu, K. S., Anderson, J. T., Hindman, L. J., Seidel, G. 2007. Diurnal foraging activities of Mute Swans in Chesapeake Bay, Maryland. - Waterbirds 30: 121-128.

[31] Weathers, W. W., Sullivan, K. A. (1993): Seasonal patterns of time and energy allocation by birds. - Physiological Zoology 66: 511-536.

[32] Woodin, M. C., Michot, T. C. (2006): Foraging behavior of Redheads (Aythya americana) wintering in Texas and Louisiana. - Hydrobiologia 567: 129-141. 